Yeti Andriani dan Andre | Implikasi Perjanjian Kemitraan Ekonomi Komprehensif Indoensia-Australia (IA-CEPA) terhadap Perdagangan Luar Negeri Indonesia

\title{
Implikasi Perjanjian Kemitraan Ekonomi Komprehensif Indonesia-Australia (IA-CEPA) terhadap Perdagangan Luar Negeri Indonesia
}

\author{
Yeti Andriani dan Andre* \\ hubungan.internasional@univrab.ac.id
}

\begin{abstract}
Abstrak
This research is used to see IA-CEPA's contribution to trade of both countries especially to Indonesian foreign trade. With the research question, what is the economic implication of this economic partnership agreement politics, especially related to Indonesian trade sector? Adam Smith's theory in this research is that the liberal economy is closely related to the world economic development, an idea that requires the liberty of individuals or economic units to achieve their interests and an invisible hand can facilitate economic regulation and achieve high economic efficiency and growth, the government should not interfere and instead let the market run on its own mechanism. Added by David Ricardo that mutual interest is generated is a mutual interest-based benefit of the trade. The method used is qualitative method that is method with purpose to explain topic in detail. The result of this research is the IA-CEPA agreement can facilitate the access of Indonesian market and foreign trade to Australia.
\end{abstract}

Key Words: Liberal Economics, IA-CEPA, Trade

*Staf Pengajar Jurusan Ilmu Hubungan Internasional Universitas Abdurrab 
Yeti Andriani dan Andre | Implikasi Perjanjian Kemitraan Ekonomi Komprehensif Indoensia-Australia (IA-CEPA) terhadap Perdagangan Luar Negeri Indonesia

\section{Pendahuluan}

Selain menjadi anggota ASEAN, secara geografis sumber daya alam Indonesia dan Australia memiliki peran penting. Indonesia menempati peringkat ke 11 sebagai mitra dagang Australia dan peluang pasar bagi Australia ${ }^{1}$. Selain itu hubungan kerjasama kedua negara menjadi strategic partner, dimana Australia juga menjadi peluang pasar baru bagi Indonesia ${ }^{2}$.

Bentuk kerjasama yang dilakukan ialah penurunan bea cukai produk Indonesia hingga $0 \%$ diiringi peningkatan standar produk Indonesia untuk memenuhi standar produk Australia ${ }^{3}$. Berikut perdagangan Indonesia ke Australia dan investasi Australia ke Indonesia :
Tabel 1

Perdagangan Indonesia-Australia

\begin{tabular}{|l|l|l|l|l|}
\hline No & Model & Tahun & Total & Jenis \\
\hline 1 & Perdagangan & 2013 & $\begin{array}{l}4,8 \text { miliar \$ } \\
\text { AS }\end{array}$ & $\begin{array}{l}\text { Emas, Baja, } \\
\text { Kayu }\end{array}$ \\
\hline 2 & Investasi & 2012 & $\begin{array}{l}743,6 \text { juta \$ } \\
\text { AS }\end{array}$ & Modal \\
\hline
\end{tabular}

Sumber: Satyagrana "Indonesia Australia sepekat meningkatkan perdagangan dan investasi”, link: http://m.antarnews.com/berita/ Indonesia_Australia_sepekat_meningkatkan_perdagangan_ dan_investasi, akses: kamis, 15/01/15, pukul 22:14

Menurut penelitian ISP (Indeks Spesialisasi Produk), Indonesia masih cenderung importir. Disisi lain dibidang manufaktur, Indonesia lebih cenderung eksportir. Hal ini menandakan Indonesia masih dalam tahap pertumbuhan ${ }^{4}$. Berdasarkan uraian singkat diatas maka penulis ingin meneliti tentang bagaimana implikasi IA-CEPA ini terhadap perdagangan luar negeri Indonesia?.

${ }^{4}$ Kemendag.ISP, link:

http://www.kemendag.go.id/addon/isp. Diakses pada pukul 11:30 WIB

\footnotetext{
${ }^{1}$ Cipto Bambang. Hubungan Internasional di Asia Tenggara (Yogyakarta : Pustaka Belajar, 2005), hlm.6

${ }^{2}$ Wahyu Sabda Kuncahyo,'Indonesia pererat hubungan dagang dengan pemerintahan Australia" http://www.rmol.co/read/2013/10/01/ indonesia_pererat_hubungan_dagang_dengan_pemer intahan_australia, diakses pada pukul 22:24 WIB

${ }^{3}$ Kementrian Perdagangan RI," hubungan Indonesia Australia menuju peningkatan perdagangan yang komprehensif melalui IA-CEPA, link: http://ditjenkpi.kemendag.go.id/websitekpi/m.dex.php?modulenews detailnews id=true. Diakses pada pukul 22:30 WIB
} 
Yeti Andriani dan Andre | Implikasi Perjanjian Kemitraan Ekonomi Komprehensif Indoensia-Australia (IA-CEPA) terhadap Perdagangan Luar Negeri Indonesia

1. Teori Ekonomi Liberal

Teori ekonomi liberal (Adam Smith) adalah sebuah teori turunan dari teori liberalisasi. Kaum liberalisasi menghargai kebebasan diatas segalanya dan percaya bahwa tindakan-tindakan negara yang dapat menghilangkan kebebasan harus dibatasi. Kekuasaan negara konstitusional liberalisasi dibatasi oleh pertanggungjawaban demokratisnya kepada warganya, untuk kebutuhan menghargai tuntutan ekonomi pasar dan aturan hukum 5 .

Pemikiran liberalisme ekonomi berasal dari Adam Smith melalui bukunya Wealth of Nations (1776), yang meyakini bahwa untuk mencapai efisiensi dan pertumbuhan ekonomi yang tinggi, pemerintah tidak seharusnya ikut campur dan justru membiarkan pasar berjalan pada mekanismenya sendiri.

Kemudian pendapat ini dikuatkan dengan konsep keunggulan komparatif milik David Ricardo, dimana proses produksi ekonomi akan lebih efisien ketika setiap aktor mengkhususkan produksinya yang menghasilkan keuntungan terbesar. Dengan

${ }^{5}$ Griffin Martin. Lima Puluh Pemikir Studi hubungan Internasional. (Jakarta: PT. Raja Grafindo Persada.2001) Hlm.266 demikian dalam aktivitas perdagangan bebas yang lintas batas, setiap negara akan memperoleh keuntungan yang maksimal melalui efisiensi, dan kesejahteraan global akan meningkat. Sehingga dalam perspektif liberalisme ini setiap individu akan memperoleh keuntungan ketika ia terlibat dalam pasar, dan kesejahteraan individu akan lebih terjamin. Dengan demikian, perekonomian internasional seharusnya didasarkan pada perdagangan bebas ${ }^{6}$.

\section{Konsep}

1. Perdagangan bebas

Menurut David Ricardo, perdagangan bebas adalah aktivitas komersial yang dijalankan secara bebas dari perbatasan nasional sehingga akan membawa keuntungan bagi setiap individu yang berpartisipasi, karena perdagangan bebas menghasilkan spesialisasi yang mampu meningkatkan efesiensi dan meningkatnya produktivitas. Dua teori kaum klasik pada perdagangan bebas:

a. Comparative advantage

\footnotetext{
${ }^{6}$ Robert H. Jackson dan Georg Sorensen. Ekonomi Politik Internasional dalam Pengantar Studi Hubungan Internasional [terj.]. (Yogyakarta: Pustaka Pelajar. 2009) Hlm. 227-277
} 
Yeti Andriani dan Andre | Implikasi Perjanjian Kemitraan Ekonomi Komprehensif Indoensia-Australia (IA-CEPA) terhadap Perdagangan Luar Negeri Indonesia

David Ricardo menambahkan bahwa

Asumsi

absolute advantage yang dikemukakan Smith dapat berlaku pada perdagangan dalam negeri, dijalankan atas dasar ongkos tenaga kerja, karena persaingan bebas dan kebebasan bergerak dari faktor produksi tenaga kerja dan modal.

\section{b. $\quad$ Absolute advantage}

Adam smith mengemukakan idenya bahwa pembagian kerja internasional berpengaruh pada peluasan pasar dan serta pada spesialisasi internasional (negara akan menekan produksinya pada barangbarangnya sesuai keuntungan yang dimilikinya, baik keuntungan alamiah maupun keuntungan perkembangan yang memberi hasil pada manfat perdagangan yang timbul dari dalam atau berupa kenaikan produksi dan konsumsi barang dan jasa

\section{Argumen}

Ekonomi liberal adalah mekanisme pasar, menumbuhkan inisiatif dan kreasi masyarakat dalam mengatur kegiatan ekonomi.

1. Diakuinya hak milik perorangan secara luas bahkan hampir tanpa batas.

2. Manusia dipandang semata-mata sebagai "makhluk ekonomi" yang tentu saja selalu ingin memaksimalkan keuntungan.

3. Pada semua individu diakui adanya motif ekonomi yang mengejar keuntungan maksimal.

4. Adanya kebebasan untuk berkompetisi antar individu.

5. Adanya mekanisme pasar yang mengatur persaingan dan kebebasan tersebut. Mekanisme pasar untuk mencapai keseimbangan terjadi secara spontan dan alami, tanpa campur tangan pemerintah (the principle of invisible hands).

\section{Skema Berpikir}

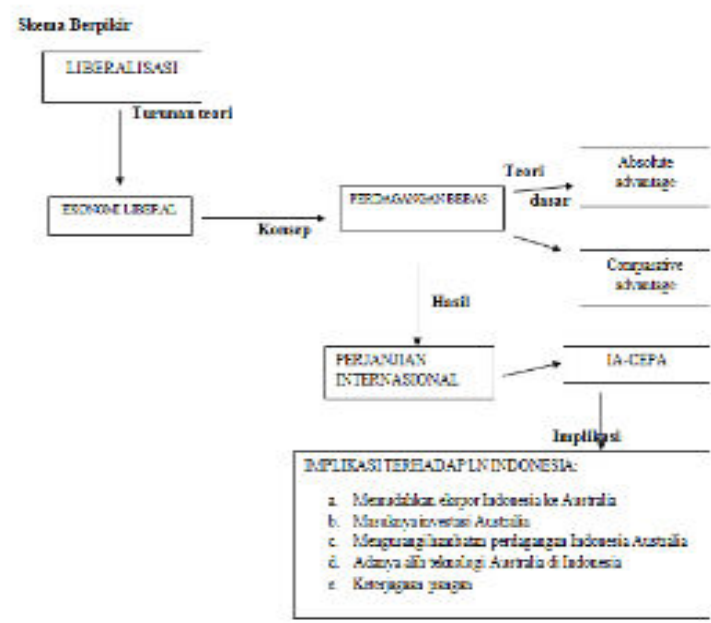


Yeti Andriani dan Andre | Implikasi Perjanjian Kemitraan Ekonomi Komprehensif Indoensia-Australia (IA-CEPA) terhadap Perdagangan Luar Negeri Indonesia

\section{Metode Penelitian}

Metode penelitian digunakan yaitu metode kualitatif dengan tujuan yang ingin dicapai dengan menjelaskan topik secara detail dengan bersumber pada perihal mendukung seperti buku, jurnal, artikel lainnya yang dianggap membantu dalam penulisan tersebut.

\section{Pembahasan}

\section{Kerjasama perjanjian Ekonomi komprehensif Indonesia-Australia (IA- CEPA)}

Perjanjian IA-CEPA ini juga mengarah terhadap perjanjian perdagangan bebas (free trade agreement), maksud kehadiran IA-CEPA ini untuk memperkuat dan memperluas ruang perdagangan, investasi, dan kerjasama ekonomi antara Australia dan Indonesia ${ }^{7}$. Perjanjian IACEPA ini merupakan suatu kesempatan untuk menciptakan langkah perubahan dalam hubungan Indonesia dan Australia karena kedua negara akan memasuki suatu tahapan kerjasama dan hubungan baik yang

\footnotetext{
${ }^{7}$ Dina,'Indonesia-Australia comprehensive economic partnership agreement negotiations", link: http://www.dfat.gov.au/fta/iacepa/index.html. Diakses pada 1 September 2014, pukul 20:00 WIB
}

belum ada sebelumnya ${ }^{8}$. Dalam kesepakatan ini, Indonesia maupun Australia menargetkan total perdagangan sebesar USD 15 miliar pada tahun 2015. Perjanjian Ekonomi komprehensif Indonesia Australia ini memiliki tujuan tiga rangkaian kegiatan yaitu: Perdagangan; Penanaman modal atau investasi; Kerjasama yang memiliki kemampuan pembangunan (capacity building), sektor yang telah disetujui pada praperundingan yang lalu, yaitu sektor agraria, pertambangan, jasa, serta perekonomian hijau 9 .

Dalam setiap perjanjian kerjasama kedua negara tersebut terikat kontrak untuk saling bekerjasama dengan baik dan tidak ikut campur dalam urusan rumah tangga negara yang bekerjasama dengannya, contohnya kerjasama Ekonomi komprehensif Indonesia Australia (IACEPA), ada rangkaian kerjasama yang harus dijalankan oleh kedua negara. Salah satunya seperti perdagangan. Jika dilihat dari

\footnotetext{
${ }^{8}$ Ibid no.8

9 Pullman Bali Legian Nirwana" Keynote address to the Indonesia Australia Business Council Conference/Australian Business Asia Regional Business Forum, link: http://www.trademinister.gov.au/speeches/2011/ce_s p_111119.html. Diakses pada 1 September 2014, pukul 20:54 WIB
} 
Yeti Andriani dan Andre | Implikasi Perjanjian Kemitraan Ekonomi Komprehensif Indoensia-Australia (IA-CEPA) terhadap Perdagangan Luar Negeri Indonesia

liberalisasi perdagangan, perjanjian Ekonomi komprehensif Indonesia Australia ini:Perjanjian perdagangan Indonesia Australia diperkirakan dapat membawa keuntungan, meski sedikit namun berdampak pada awal gross national product (GNP ekonomi), pada 20 tahun yang akan datang tepatnya tahun 2030 nanti, akan berdampak pada GNP Australia meningkat $0,02 \%$ lebih dan GNP Indonesia $0,23 \%$ lebih.

a. Faktanya bagi Indonesia keuntungan dari perjanjian perdagangan ini merupakan refleksi dari hubungan perdagangan dan besarnya hambatan perdagangan itu, hambatan perdagangan Indonesia untuk Australia, sedangkan Australia merupakan rekan perdagangan yang penting bagi Indonesia sekarang ini dan juga sebaliknya, Indonesia merupakan rekan kerja yang penting bagi Australia.

b. Sejak tahun 2010-2030 nanti, Australia memperkirakan dapat memperoleh keuntungan sebesar \$3,2 miliar dihitung dengan GNP tahun 2008, dibanding dengan Indonesia \$33,1 miliar.

c. Perjanjian perdagangan Indonesia dan Australia ini sudah dijalankan sejak diadakan perjanjian perdagangan dan investasi ASEAN-Australia-New Zealand Free Trade Agreement (AANZTA).

d. Pada tahun 2011, perdagangan dua arah untuk barang dan jasa mencapai $\$ 14,8$ $M$ dan \$14,9 M menjadi defisit \$11,9 M pada tahun $2013^{10}$. Australia mencatat defisit perdagangan sebesar A $\$ 1,5 \mathrm{M}$ dengan Indonesia dalam tahun $2011^{11}$. Indonesia adalah mitra dagang Australia keempat terbesar di ASEAN dan mitra dagang ke-12 terbesar secara keseluruhan dan pasar ekspor ke-11 terbesar. Sebaliknya, Australia adalah mitra dagang ke 9 terbesar bagi Indonesia dan pasar ekspor ke 9 terbesar. Ekspor Australia pada Indonesia:
a. wheat (\$1,2 M pada 2013)
b. sugar, molasses and honey (\$363 M)
c. live animals (termasuk seafood, \$302 M)
d. aluminium $(\$ 284 \mathrm{M})$
e. crude petroleum $(\$ 207 \mathrm{M})$
f. $\operatorname{cotton}(\$ 195 \mathrm{M})$

Dua servis perdagangan Australia untuk Indonesia meningkat $\$ 3,7 \mathrm{M}$ pada tahun 2013, untuk servis ekspor ke

\footnotetext{
${ }^{10}$ Indonesia country brief-departement or foreign affairs and trade”,

link: http//dfat.gov.au/geo/indonesia/pages/indonesiacountry-brief.aspx

${ }^{11}$ DFAT

(http://www.dfat.gov.au/geo/indonesia/indonesia_bri ef.html) \& BKPM \& BPS- Statistik Indonesia
} 
Yeti Andriani dan Andre | Implikasi Perjanjian Kemitraan Ekonomi Komprehensif Indoensia-Australia (IA-CEPA) terhadap Perdagangan Luar Negeri Indonesia

Indonesia $44.8 \%$ dan servis distribusi atau travel sebesar $74.9 \%{ }^{12}$.

Indonesia dan Australia adalah hubungan Ekonomi yang saling melengkapi dilihat dari:

\section{a. Revealed Symmetric Comparative} Advantage (RSCA) indeks, rentang hitungan RSCA ini -1 sampai 1, dalam hitungan global ekonomi, jika dibawah -1 maka negara itu disadvantage, dengan RSCA ini kita dapat melihat peningkatan perdagangan yang terjadi.

b. Trade Specialisation Index (TSI) dan Indeks Spesialisasi Perdagangan (ISP) ${ }^{13}$, digunakan untuk menganalisis luasnya daya saing ekspor dan impor dalam kerjasama bilateral tersebut, dengan range -1 sampai 1.

c. Bilateral Trade Intensity, hal ini digunakan untuk melihat persamaan ekspor antara Indonesia dan Australia dengan ekspor dunia.

d. Intra-industry Trade Index, dilihat dari perdagangan dua negara dengan industri, dengan range $0-1$.

e. $\quad$ Trade Complementarity Index.

\footnotetext{
12 Ibid no, 8

${ }^{13}$ Kemendag "Indeks Spesiasisasi Harga(ISP), link: http://www.kemendag.go.id/addon/isp/. Diakses pada 1 September 2014, pukul 22:38 WIB
}

\section{Pola Kerjasama Indonesia Australia}

Kerjasama perdagangan Indonesia dan Australia merupakan kerjasama komplementer, dalam kerjasama perdagangan ini Indonesia menyediakan bahan dasar dan produk manufaktur seperti : crude palm oil, cocoa products, wood product, paper and paper broad, ruber tyre and ect, sedangkan Australia menjadikan Indonesia sebagai pasar meat and dairy product, wheat, mineral product, as will services sector (service travel and business service) mereka ${ }^{14}$. Kerjasama perdagangan antara Indonesia dan Australia telah terjadi sejak tahun 1999, pada saat itu juga terjadi ekspor Australia ke Indonesia, diiringi dengan krisis keuangan di Asia dan kemudian berpengaruh pada impor Indonesia. Meski kerjasama kedua negara ini selalu dalam krisis, mulai krisis keuangan Asia sampai dengan krisis global, namun kerjasama perdagangan kedua negara bergerak secara perlahan pertahunnya, hingga semakin kuat pada tahun 2006. Dalam tahun 2006, Australia menjadikan

\footnotetext{
${ }^{14}$ Herry Suetanto,"Head of the agency for trade policy analysis and development ministry of trade, Republik of Indonesia Australia Indonesia business coference, Sydney 7 March 2011, link: http/www.aibc-coference-ia-cepa-20110307.pdf. Diakses pada 26 Juni 2014
} 
Yeti Andriani dan Andre | Implikasi Perjanjian Kemitraan Ekonomi Komprehensif Indoensia-Australia (IA-CEPA) terhadap Perdagangan Luar Negeri Indonesia

Indonesia menempati sebagai 10 besar pasar ekspornya dan urutan ke-12 sumber negara pengimpor bagi Australia, sedangkan Indonesia menempatkan Australia sebagai tempat ke-8 untuk ekspor pasar Indonesia dan urutan ke-8 juga sebagai negara pengimpor bagi Indonesia. Jika dilihat Indonesia dan Australia merupakan trading patner yang solid.

Dukungan kedua negara terhadap kerjasama kemitraan ekonomi komprehensif Indonesia Australia:

a. Pada 17 Maret 2010 di Canberra, Presiden Susilo Bambang Yudhoyono mengatakan Australia dan Indonesia mempunyai masa depan bersama yang baik. "Kita bukan saja bertetangga, bukan hanya sahabat; kita adalah mitra strategis. Kita adalah pemangku kepentingan yang setara bagi masa depan bersama dimana banyak yang akan didapat apabila kita bina hubungan ini secara benar dan kita akan rugi banyak apabila kita salah mengelolanya. Kita perlu mendorong sektor swasta untuk melakukan bisnis satu sama lain."

b. Pada 3 November 2010 di Jakarta, Perdana Menteri Australia Julia Gillard mengatakan, "Saya senang hari ini karena hubungan kita menguat, kita telah berhasil menyetujui kedua negara membentuk kemitraan ekonomi menyeluruh, yang bukan hanya memahami liberalisasi perdagangan lebih jauh namun menangani masalah ekonomi secara menyeluruh yang membawa negara kita bersama, termasuk investasi, hubungan antara dunia usaha dan pengembangan kapasitas."

c. Pada 20 November, 2011, Menteri Perdagangan Australia mengatakan, "Jurang antara hubungan ekonomi sebenarnya dan potensi yang ada cukup bisa."

d. Pada 15 Oktober 2012 di Jakarta, Presiden Susilo Bambang Yudhoyono pada World Ekspor Development Forum (WEDF) mengatakan, "Pertama, pasar pertumbuhan perlu memprioritaskan fasilitasi perdagangan dengan mengembangkan infrastruktur keras maupun lunak. Kedua, pasar pertumbuhan perlu menangani hambatan perdagangan yang ada. Dan yang ketiga, pasar pertumbuhan harus dapat menangani jurang mata rantai pasokan dan peluang. Mata rantai pasokan global sangat kritis bagi perdagangan dunia." 
Yeti Andriani dan Andre | Implikasi Perjanjian Kemitraan Ekonomi Komprehensif Indoensia-Australia (IA-CEPA) terhadap Perdagangan Luar Negeri Indonesia

Penandatangan perjanjian kemitraan ini lebih cenderung pada perdagangan yang lebih bebas dan perekonomian yang global, dengan jadinya Indonesia dan Australia menjadi anggota AANZTA dapat menciptakan dasar dari perdagangan yang lebih terbuka. Cara perjanjian IA-CEPA mempermudah dan mengembangkan akses pasar Indonesia ialah dengan:

\section{c. Memudahkan melakukan ekspor Indonesia ke Australia.}

Salah satu contoh ekspor Indonesia ke Australia ialah ekspor buah-buahan tropis Indonesia seperti buah manggis. Ekspor manggis Indonesia berhasil menembus akses pasar buah Australia. Ekspor perdana buah manggis dilakukan oleh PT. Agung Mustika Selaras, Tangerang pada 27 September 2012 selaku eksportir Indonesia. Berdasarkan data dari Kementerian Perdagangan Indonesia produksi manggis nasional pada tahun 2011 mencapai 117.600 ton dengan jumlah ekspor 12.600 ton dengan nilai 9,9 juta dolar AS setara dengan Rp. 94 miliar ${ }^{15}$, pengeksporan manggis ke Australia melalui jalur udara,

\footnotetext{
${ }^{15}$ Sibertama, “ Ekspor Hortikultura: Indonesia rintis pasar Manggis di Australia/industri-bisnis.com mobile", link:

http://m.bisnis.com/industri/read/20121209/99/10879

7/ekspor-hortikultura-indonesia-industri-pasa-

manggis-di-australia. Diakses pada 5 Mei 2015
}

dan diharapkan hal ini menjadi langkah awal membuka perdagangan kedua negara menjadi yang lebih besar. Tujuan ekspor manggis selama ini adalah Hongkong, China, Singapura, Malaysia, dan Timur Tengah dan kedepannya pemerintah mengupayakan pengeksporan buah-buahan tropis lainnya seperti salak, mangga dan yang lainnya ke Australia dan negara mitra dagang lainnya. Hal ini membuktikan bahwa produk Indonesia dapat bersaing di dunia Internasional ${ }^{16}$. Ekspor bahan pangan dan buah-buahan Indonesia ke Australia mengalami potensi yang baik. Untuk semua kegiatan ekspor Indonesia ke Australia hanya mengalami kesulitan pada penyesuaian standar Australia karena salah satunya buruknya rantai pengantar internal (distribusi) dan infrastruktur seperti kondisi transportasi sehingga produk membusuk dan akhirnya terbuang. Ekspor dilakukan Indonesia ini juga berkenaan dengan niat, yang IA-CEPA ini juga menjadikan Indonesia-Australia sebagai negara

\footnotetext{
${ }^{16}$ Helen Brown, ”Eksportir buah Indoensia mengirim produk ke Australia/ABC Radio Australia", link: http://m.radioaustralia/2012-12-29/eksportir-buahbuahan-dari-indoensia-mengirim-produk-keaustralia/1053526. Diakses pada 5 Mei 2015
} 
Yeti Andriani dan Andre | Implikasi Perjanjian Kemitraan Ekonomi Komprehensif Indoensia-Australia (IA-CEPA) terhadap Perdagangan Luar Negeri Indonesia

penghasil dan pengekspor makanan nomor satu di Asia ${ }^{17}$.

\section{d. Adanya pemasukkan investasi dari} Australia ke Indonesia membuat perdagangan Indonesia tidak lagi kekurangan modal, dengan demikian dapat memperluas pasar dan mengembangkan perdagangan di Indonesia.

Menurut James Bond, Australian services round table, Australia memiliki cadangan dana lebih kurang sebesar A\$ 1,4 triliun yang tersedia untuk investasi dan Australia sangat suka melakukan investasi di luar negeri. Kerjasama ekonomi yang dilakukan oleh Indonesia dan Australia memiliki keuntungan untuk kedua negara dan Indonesia bisa menjadi target investasi oleh Australia, hanya sektor pertambangan yang tidak dijangkau oleh investasi Australia karena pembatasan dan peraturan investasi asing. Gaya investasi Australia ialah investasi bebas dan begitu juga Indonesia, sehingga investasi yang

${ }^{17}$ Ibid, no.3 dirancang dalam IA-CEPA ini mengalami investasi asing yang timbal balik ${ }^{18}$.

Pada tahun 2011, nilai investasi Australia di Indonesia mencapai 87,7 juta dolar Amerika Serikat, sedangkan pada tahun 2012 investasi Australia di Indonesia mencapai 743,6 juta dolar Amerika Serikat. Dilihat dari sisi investasi di Indonesia, Australia menempati peringkat ke-12 sebagai negara investasi di Indonesia. Seperti Robert Reich, "peran pemerintah bukan hanya meratakan kemakmuran, tetapi juga membangun sumber daya manusia dan infrastruktur secara berunding dengan modal global untuk kepentingan masyarakat" ${ }^{19}$. Dari kutipan ini penulis dapat mengatakan investasi yang dilakukan Australia atas dasar perundingan dengan pemerintah Indonesia dan persetujuan kedua negara.

\section{e. Mengurangi}

\section{hambatan}

\section{perdagangan internasional.}

Saat ini ekspor barang Australia ke Indonesia akan mendapatkan bebas Bea masuk atau Bea impor dari sebesar 56\% menjadi 92\%, dari seluruh jenis komoditi

\footnotetext{
${ }^{18}$ Ibid no.8

${ }^{19}$ Euromoney 5 September 1993, kutipan berasal dari Reich 1991, Robert Reich menjadi Mentri Perburuan dibawah Presiden Clinton
}

Andalas Journal of International Studies | Vol 6 No 1 Mei Tahun 2017 
Yeti Andriani dan Andre | Implikasi Perjanjian Kemitraan Ekonomi Komprehensif Indoensia-Australia (IA-CEPA) terhadap Perdagangan Luar Negeri Indonesia

barang yang diekspor Australia ke Indonesia, sedangkan 5\% lainnya akan mendapatkan tarif bea masuk tidak lebih dari 5\%. Bagi Indonesia, 99\% ekspornya ke Australia akan menikmati bebas Bea masuk, dan akan menjadi 100\% bebas Bea masuk pada saat perjanjian secara penuh diimplementasikan ${ }^{20}$.

Implikasi yang dimaksud dalam perjanjian ini adalah keterlibatan atau keadaan terlibat antara interaksi ekonomi dengan tindakan politik dalam penyelesaian masalah yang terjadi dalam kehidupan sosial, ekonomi, politik dan lainnya.

Menurut Australia government department of foreign afairs and trade tahun 2013, hubungan dagang Indonesia dan Australia masih relatif rendah. Pada tahun 2012, ekspor barang dari Australia ke Indonesia hanya mencapai $2.0 \%$ dari total ekspor Australia ke seluruh dunia. Sedangkan impor Indonesia ke Australia hanya mencakup $2,6 \%$ dari total impor Australia, sedangkan menurut Badan Koordinasi Penanaman Modal (BKPM) tahun 2013, bagi Indonesia tujuan ekspor ke Australia hanya mencakup 2,7\% dan 2.6\%

\footnotetext{
${ }^{20}$ Kementrian luar negeri Indonesia, Perdagangan Indonesia-Australia, Tabloid diplomasi, edisi Maret 2012
}

tujuan impor Indonesia. Dilihat dari sisi Investasi Langsung Asing (Foreign Direct Investment), Australia hanya 3,0\%. Australia memasukkan inisiatif nya pada white paper tentang penghapusan hambatan perdagangan merupakan hal yang baik bagi hubungannya dengan negara Asia terutama Indonesia $^{21}$.

\section{f. Implikasi yang ditimbulkan dibidang ekonomi politik terhadap perdagangan adalah: melakukan alih teknologi atau berbagi teknologi}

Charles Freeman Jr. menegaskan kekuatan merupakan kapasitas untuk mengarahkan keputusan dan tindakan pada pihak lain, kekuatan berasal dari ketahanan dan keamanan, ketahanan berasal dari tranportasi sumber daya menjadi kemampuan dan kemampuan akan mengubah masalah jadi solusi ${ }^{22}$. Australia bisa dikatakan negara yang memiliki teknologi yang cukup baik untuk melakukan

\footnotetext{
${ }^{21}$ Feisal "Perspektif Indonesia di The Asian Century White Paper?/PPIA ACT”, link: htpp://ppiaact.org/2013/05/13/prespektif_indonesia_di_the_asia n_century_whet_paper/. Diakses pada $1 \overline{8}$ Mei $20 \overline{0} 15$

${ }^{22}$ Marcella Gabriel, "National Security An Integrancy Proses," in U.S. Army War College Guide To National Security Policy And Strategy, ed. J. Boone Bartholomees, Carlisle, PA : Strategic Studies Institute, U.S. Army War College, 2010
} 
Yeti Andriani dan Andre | Implikasi Perjanjian Kemitraan Ekonomi Komprehensif Indoensia-Australia (IA-CEPA) terhadap Perdagangan Luar Negeri Indonesia

berbagi teknologi dengan Indonesia. Seperti yang ditegaskan Ketua Kamar Dagang Australia (ACCI) Peter Aderson disurat kabar Merdeka di Jakarta pada hari Kamis, 18/10/2012: “teknologi yang kami punya akan dikombinasikan dengan pemerintah Indonesia untuk menyelesaikan problem infrastuktur, dan tentu sebaliknya masalah kekurangan keterampilan pekerja di Indonesia" .

Dua teknologi yang dialihkan ke Indonesia :

\section{Benchmark}

Digunakan untuk pengembangan teknologi pertanian dan pangan. Teknologi inilah yang digunakan untuk pengolahan pangan di Indonesia.

2. Blue Scope

Alat pada perusahaan untuk memperbanyak pembuatan logam lapis, contohnya teknologi baru ini Blue Scope dapat meningkat menjadi 265 ribu ton logam lapis (Metal Coanting) dan 160 ribu ton Metal Painting.

\section{g. Keterjagaan Pangan}

Australia dianggap Food and Agriculture Organization (FAO) sebagai negara dengan ketahanan pangan tertinggi, dalam banyak sektor pangan dan juga swasembada untuk saat ini, kedepannya Australia akan mengalami tantangan dalam produksi terkait gizi lahan atau unsur hara tanah dan jika dilihat dari tingkat endapan tanah, benua Australia merupakan benua terkering didunia, namun Australia memang subur dalam bidang pertanian.

Australia menjalin kerjasama dengan Indonesia memang kerjasama yang saling melengkapi, seperti perkataan pakar bahwa ekonomi Indonesia dengan ekonomi Australia adalah ekonomi yang bersifat complementary $^{23}$. Dari penjelasan diatas dapat dikatakan bahwa Indonesia yang bahan pangan nasionalnya belum terpenuhi dapat dilengkapi oleh Australia yang kelebihan bahan pangan dengan mengimpor bahan pangan Australia seperti gandum, susu, daging dan kebutuhan pangan lainnya

\footnotetext{
${ }^{23}$ komentar yang muncul dari Centre for International Economics (CIE) dalam laporan Estimating the Impact of an Australia-Indonesia Trade and Investment Agreement, (2009). Bab IInyaMembahas pertanyaan itu, dan menyimpulkan :“...dari lima sistem ukuran tersebut maka Australia dan Indonesia Mempunyai pola-pola produksi dan konsumsi yang complimentary satu sama
} lain."hlm.17 
Yeti Andriani dan Andre | Implikasi Perjanjian Kemitraan Ekonomi Komprehensif Indoensia-Australia (IA-CEPA) terhadap Perdagangan Luar Negeri Indonesia

yang dibutuhkan. Kecukupan pangan akan menstabilkan ekonomi politik di Indonesia sehingga perjanjian ini berimplikasi baik pada ekonomi politik Indonesia, liberal juga mengatakan hubungan internasional sebagai wilayah kemajuan dan perubahan, karena negara maju dan berkembang memiliki rasa interdependensi dan kerjasama dalam mengejar kepentingan bersama merupakan ciri utama politik dunia ${ }^{24}$.

\section{Kesimpulan}

Indonesia Australia mampu menjalin kerjasama dengan baik dan memperlancar kerjasama kembali setelah rusaknya kerjasama terdahulu Indonesia Australia melalui perjanjian IA-CEPA. Perdagangan luar negeri Indonesia ke Australia berjalan dengan baik dengan minimnya bea tarif cukai Australia terhadap produk Indonesia.

\section{Daftar Pustaka}

Cipto, Bambang. Hubungan Internasional di Asia Tenggara, (Yogyakarta : Pustaka Belajar, 2010) halaman 206

\section{DFAT}

(http://www.dfat.gov.au/geo/indonesia /indonesia_brief.html) \& BKPM \& BPS- Statistik Indonesia

Dina,"Indonesia-Australia comprehensive economic partnership agreement negotiations", link: http://www.dfat.gov.au/fta/iacepa/inde x.html, diakses: Senin,01-September2014, pukul 20:00 WIB

Euromoney 5 September 1993, kutipan berasal dari Reich 1991, Robert reich menjadi mentri perburuan dibawah presiden Clinton

Feisal"prespektif Indonesia di the asian century white ppaper?/PPIA ACT", link: htpp://ppiaact.org/2013/05/13/prespektif_indones ia_di_the_asian_century_whet_paper/ , diakses: Senin 18/05/2015

Griffin Martin (2001)"organisasi internasional"Ed.1, lima puluh pemikiran studi HI, jakarta : Pt. Raja Grafindo Persada, Hlm.266

Helen Brown" eksportir buah Indoensia mengirim produk ke Australia/ABC Radio Australia", link:http://m.radioaustralia/2012-1229/eksportir-buah-buahan-dariindoensia-mengirim-produk-keaustralia/1053526, diakses: Selasa, $05 / 05 / 2015$

Herry Suetanto,"head of the agency for trade policy analysis and development ministry of trade, Republik of Indonesia Australia Indonesia business coference, Sydney 7 March 2011, link: http/www.aibc-coference-

${ }^{24}$ Ibid no. 22

Andalas Journal of International Studies | Vol 6 No 1 Mei Tahun 2017 
Yeti Andriani dan Andre | Implikasi Perjanjian Kemitraan Ekonomi Komprehensif Indoensia-Australia (IA-CEPA) terhadap Perdagangan Luar Negeri Indonesia

ia-cepa-20110307.pdf, diakes: Kamis, 26 Juni 2014

Indonesia country brief-departement or foreign affairs and trade", link: $\mathrm{http} /$ dfat.gov.au/geo/indonesia/pages/i ndonesia-country-brief.aspx

Jackson, Robert \& Sorensen, Georg. 2009. "Ekonomi Politik Internasional" dalam Pengantar Studi Hubungan Internasional [terj.]. Yogyakarta: Pustaka Pelajar, hlm. 227-277

Kementrian luar negeri Indonesia, Perdagangan Indonesia-Australia, Tabloid diplomasi, edisi maret 2012

Kementrian perdagangan RI," hubungan indonesia australia menuju peningkatan perdagangan yang komprehensif melalui IA-CEPA, link: http://ditjenkpi.kemendag.go.id/websit e

kpi/m.dex.php?modulenews_detailne ws_id=true, pukul 22:30 wib

Kemendag.ISP, link: http://www.kemendag.go.id/addon/isp, pukul 11:30 wib

Kemendag"indeks spesiasisasi harga(isp), link:

http://www.kemendag.go.id/addon/isp/ , diakses: Jum'at, 16/01/2015, pukul 22:38 WIB
Marcella Gabriel(July 2004),"chapter 17: national security an integrancy proses", in Bartholomees, Jr, J,Boone US army war college guide to national security policy an strategy: united state army war college, p.239-260

Pullman Bali Legian Nirwana" Keynote address to the Indonesia Australia Business Council Conference/Australian Business Asia Regional Business Forum,link: http://www.trademinister.gov.au/speec hes/2011/ce sp 111119.html, diakses: Senin-01-September 2014, pukul 20:54 WIB

Sibertama “ ekspor Hortikultura: Indonesia rintis pasar Manggis di Australia/industri-bisnis.com mobile", link:

http://m.bisnis.com/industri/read/2012 1209/99/108797/ekspor-hortikulturaindonesia-industri-pasa-manggis-diaustralia, diakses: Selasa, 05/05/2015

Wahyu sabda kuncahyo" indonesia pererat hubungan dagang dengan pemerintahan australia",link:http://www.rmol.co/rea $\mathrm{d} / 2013 / 10 / 01 /$ indonesia pererat hubu ngan_dagang_denga_pemerintahan_au stralia, pukul 22:24 wib 